\title{
Instructional Differential Analysis of Discourse by SDIS-GSEQ: IRE in the Teaching-Learning Process in Nursing
}

\author{
Edgardo Ruiz Carrillo, Patricia Suárez Castillo, Cruz González José Luis \\ Universidad Nacional Autónoma de México-Facultad de Estudios Superiores Iztacala, Estado, México \\ Email: Edgardo@unam.mx,patric@unam.mx, jlcgsiruscapella@gmail.com
}

Received 16 March 2016; accepted 24 April 2016; published 27 April 2016

Copyright $@ 2016$ by authors and Scientific Research Publishing Inc.

This work is licensed under the Creative Commons Attribution International License (CC BY).

http://creativecommons.org/licenses/by/4.0/

c) (i) Open Access

\begin{abstract}
In order to analyze the teacher and practicing students' guidance differences in the teachinglearning process in the nursing practices, we elaborated observations and analysis of speech on a classroom of the nursing degree in the Facultad de Estudios Superiores Iztacala, of the Universidad Nacional Autónoma de México, with 30 second-semester nursing students (7 men, 23 women between 19 - 21 years old), 5 eight-semester practicing nursing students (1 man, 4 women between 21 - 22 years old), and a nursing teacher as participant. The recording, transcription and coding of what was observed in the recorded class, was later analyzed applying the SDIS-GSEQ software to generate sequential connections of the participants' speech. By analyzing the flows of the speech, we found that the teacher and practicing students' ways of instructing during class are differentially held due to the structures of speech used as well as the use of the model, making it possible for the students to have meaningful learning when acquiring professional and clinical attitudes. There is variability between practicing students and the teacher when developing the same category of educational action in learning. The practicing students motivate the student to acquire the theoretical knowledge while the teacher performs a guiding and accompanying role.
\end{abstract}

\section{Keywords}

Mentors, Clinical Competence, Professional Competence, Patient Simulation, Discourse

\section{Introduction}

Learning as a social activity implies an interchange of information and resources employed, where language receives a critical use as means and action showing the inter-subjective processes. Subjectivity is understood as

How to cite this paper: Carrillo, E. R., Castillo, P. S., \& Luis, C. G. J. (2016). Instructional Differential Analysis of Discourse by SDIS-GSEQ: IRE in the Teaching-Learning Process in Nursing. Psychology, 7, 612-622. 
the group of processes constituting the reality of the subject (Anzaldúa, 2004), the reality occurring from his connection with his peers, which in turn exists within a symbolic cultural environment to which the learner is expected to integrate to.

Learning, as a co-construction process involves a continuous interchange of knowing and chores. Some psychological concepts generated on these processes are: shared knowledge (Edwards \& Mercer, 1986), scaffolding (Wood, Bruner, \& Ross, 1976) or guided participation (Rogoff, 1990); and have helped in describing teaching and learning processes as a collaboration o joined coordination of the teaching staff and the student body (Coll, Colomina, Onrubia, \& Rochera, 1992; Coll \& Onrubia, 2001; Driver, Asoko, Leach, Mortimer, \& Scott, 1994; Edwards, 1990; Edwards \& Middleton, 1986).

The meaningful aspect of learning implies its origin and function in a certain context. This placed character (Edwards, 1990) lets us interpret the speech interaction taking into account the details of its production and sequential organization so that it can be analyzed how an expression has been thought so as to carry out a certain action within the speech. These sequences make it possible to analyze how a speaker's participation generates a speech context for the next intervention, and how the use of a specific word or expression orients and supports the interchange process.

Following this thinking track, it is feasible to study knowledge construction at school in the speech and social context in which it is produced (Edwards \& Mercer, 1986), because if the speech is analyzed, this lets us comprehend how finely sequenced the turns are and how tactfully a conversation can be structured or establish some statements as truth. When students and teachers interact a shared story of speech, and activity is being built (Edwards \& Westgate, 1994) it establishes, at every lesson as a whole, the understanding of words of reference and the meanings within the speech communication forms.

The meaning within the educational speech and the dynamics in the classroom are accomplished through the "coordinated effort" of the group, being built by means of conceptions and ways of shared speeches, with which teachers and students develop activities in the room and acquire understanding from experiences, linked to specific knowledge. These lessons become the vehicle that makes the creation of a particular perspective on things possible.

To participate actively and successfully in this process, it is necessary to use the words and the resources of speech according to the rules of the particular context, for students to take ownership of the criteria that the school knowledge use, and allow legitimizing a specific explanation towards others possible and to describe a set of basic educational rules involved in the production of educational discourse (Candela, 1993, 1996, 1999).

This is how learning as a process lets someone apprehend the surrounding reality so as to understand it epistemologically, and it can be confirmed in reality by using applied knowledge. It is a formative strategy applied in the educational system which is made of reality, reflection and resolution (Hernández \& Díaz, 2012).

In this sense, the teacher-student relationship is presented as a dyad where each one inevitable plays his or her subjectivity within the institutional and social context where it is happening. The importance of this connection relies on the fact that scholar learning is organized by using discursive structures so as to face the challenges of teaching and learning (Anzaldúa, 2004).

This way, professional formation is thought as a process through which skills, attitudes and values are acquired to let us access into a certain profile which helps the professionals solve specific social problems. The simulation of labor situations is one of the strategies for teaching in nursing. In such situations a solution must be found or they are meant for experiencing a certain situation to develop some strategies of prevention and for caring for patients (Pimienta, 2012).

To study the process of teaching nursing and holding learning as a social process is crucial to understand the elements that make up interaction so that we can define the process by which students acquire knowledge-task relating in the practice of caring for others. It is through speech that these exercises are oriented and regulated. Reviewing by analyzing speech ("Discourse Analysis" or DA) lets us comprehend the learning of caring.

According to DA, reality is built up while people speak or write about the world, and it is in the everyday practice through these categories and descriptions (Potter, 1996). This way, the meanings made through a conversation by using elements are endemic to interaction (Potter, 1996; Drew, 1995). The way in which inhabitants of a community refer to the knowledge of such community makes up the reality of such society. Therefore, such recreation of reality is supported by specific patterns of communication which define the learning style to be used in the educational context.

Several authors agree with the existence of a prevailing speech pattern in the classroom called IRE, Interven- 
tion-Response-Evaluation or IRF, Intervention-Response-Feedback, which is designed as a master beginning (I), often becoming a test or a question of visualization that predicts the student's answer (R) which can or can't be the desirable information. Then, the teacher evaluates (E) the answer according to how close to the desirable answer is, or the teacher offers comments to widen the dialog (F) (Mercer, 1995). The IRE discursive processes during classes have been documented in Cazden (2001) and Stierer \& Maybin (1994), and they turned out to be inappropriate to optimize learning because they generate a turn-taking system in which the teacher assigns most of such turns of intervention and gives not many opportunities to the students to select a topic to talk about (Mercer, 1995). When the teacher applies the strategy of asking generally triggers the desirable information since they are the ones pedagogically aware of such knowledge, they are the "primary knowers" (Nassaji \& Wells, 2000).

From the implications of speech, and from the uses of various structures in the teaching-learning process, the goal is to find essential information about how teaching is presented in the classroom by the teacher and the practicing students within the process of formation of the nursing professional.

\section{Method}

\subsection{Participants}

30 second-semester nursing students ( 7 men, 23 women between 19 - 21 years old), 5 eight-semester nursing practicing students ( 1 man, 4 women, between $21-22$ years old), and a nursing teacher teaching the section about Nursing Models and Theories in the Facultad de Estudios Superior Iztacala, of the Universidad Nacional Autónoma de México (UNAM); all participants were Mexican.

\subsection{Ethical Considerations}

The work was done following the recommendations of the Psychologist's Ethics Code of the American Psychological Association (2010), which indicate to work with the participants' approval as well as using their pseudonyms to protect their identity. The participants knew when they were going to be recorded. Also, they knew their right to get the transcripts of the data that were analyzed.

\subsection{Observation Tools and Categorizing the Data}

A VIXIA HF-R50 Cannon video camera that has a SHURE VF83 external microphone was used by a researcher in the classroom so as to guarantee the best precision of collection of data. It is where a teacher with the help of $8^{\text {th }}$ semester practicing students taught students the process of assessing the patient through the physical exploration the respiratory model.

The instrument of conversion of data observed into categories of analysis is a combination between field format and systems of categories which is built by using multiple and self-regulated coding from a based theoretical frame (Anguera \& Izquierdo, 2006). The matrix generated wanted to report the complexity of the corresponding information to the communicative flow and it also modulated the dichotomy between the qualitative and quantitative methodologies required in such study.

From observing the recordings and according to the study objective the exhaustive list of interactions with reciprocal exclusivity (E/ME) of the categories was built, therefore there's a category for each feasible action and a feasible action for each category of interest. Anguera \& Izquierdo (2006) propose that with the identification of the speaker the who-to-whom structure is established in every situation of the oral interaction, this way the interactive features of the event in turn are codified taking into account the social functions (speech, connection and task) performed. Apart from duration, each turn was codified as "a whole" according to the dimensions considered.

In this way, the generated coding on the basis of the theoretical frame and the observations resulted in Table 1.

Each of the given categories was seen with certain probability of occurrence being present in any participant, so during the categorization and in order to distinguish the role of the one who categorized, at the beginning of each one an "M" was written when being presented by the teacher, a "P" when presented by a practicing student, "A" in the case of the students. And a "T" was used when more than half of the group would answer simultaneously (T > 15 A). 
Table 1. Categories of the discursive sequence, with code and definition.

\begin{tabular}{|c|c|c|c|}
\hline Category & Code & Primaryintention & Complementary intention \\
\hline \multicolumn{4}{|l|}{ Asking } \\
\hline Confirming & Preconf & \multirow{5}{*}{$\begin{array}{l}\text { Requesting expecting to } \\
\text { get information as an } \\
\text { answer with the required } \\
\text { information. }\end{array}$} & Corroborating information. \\
\hline Doubting & Predud & & Looking for some knowledge that is not known. \\
\hline Ordering & Preord & & Generate an action from the other. \\
\hline Evaluating any participant & Preeva & & Estimating knowledge and attitudes from any member of the group. \\
\hline $\begin{array}{l}\text { Evaluating a particular } \\
\text { participant }\end{array}$ & Predeva & & Estimating knowledge and attitudes from a particular person. \\
\hline \multicolumn{4}{|l|}{ Answering } \\
\hline Doubting & Redud & \multirow{8}{*}{$\begin{array}{l}\text { Answering a question } \\
\text { wanting to clarify a doubt. }\end{array}$} & Using knowledge which is not structured yet. \\
\hline Commanding & Reord & & Requesting the fulfilment of a task. \\
\hline Confirming & Reconf & & Corroboratinginformation. \\
\hline Reinterpreting & & & Using reconstructed knowledge from what it was taught. \\
\hline Explaining & Reexp & & Exhibiting knowledge to make it understandable. \\
\hline & & & Admitting missing some knowledge. \\
\hline Denying & Reneg & & $\begin{array}{l}\text { From student to student: recognizing the other student's lack of } \\
\text { knowledge. }\end{array}$ \\
\hline Asserting & Reafi & & Validating some knowledge. \\
\hline \multicolumn{4}{|l|}{ Evaluating } \\
\hline Giving feedback & Evacal & $\begin{array}{l}\text { Action that calculates the } \\
\text { validity of a supposition } \\
\text { or a subject; in the } \\
\text { environment of the } \\
\text { educational speech, of the } \\
\text { validity of the acquired } \\
\text { knowledge. }\end{array}$ & $\begin{array}{l}\text { Pointing out the level of acceptance of the others knowledge based } \\
\text { on a judgement of value. }\end{array}$ \\
\hline \multicolumn{4}{|l|}{ Instructing } \\
\hline Explaining (Onlyspeech) & Insexp & \multirow{6}{*}{$\begin{array}{l}\text { Action in which an } \\
\text { instructor (having the } \\
\text { knowledge) gives either } \\
\text { knowledge or information } \\
\text { relating to a subject to a } \\
\text { learner (inexperienced). }\end{array}$} & $\begin{array}{l}\text { Stating some knowledge to make it easier to understand through } \\
\text { speech. }\end{array}$ \\
\hline Explaining (Usingmodels) & Insmexp & & $\begin{array}{l}\text { Stating some knowledge to make it easier to understand through } \\
\text { simulating models. }\end{array}$ \\
\hline Describing & Insdes & & Detailing processes relating to the subject. \\
\hline Clarifying & Insacl & & Detailing elements of the subject. \\
\hline Guiding & Insgui & & Guiding tasks relating to the subject. \\
\hline Commanding & Insord & & Requesting fulfilment of a task. \\
\hline
\end{tabular}

Once the recordings were transcribed, the categories of analysis in each discursive action performed by the participants were used, generating a coded sequential group, which became the database. The structural analysis technique was applied, translating the SDIS language (Sequential Data Interchange Standard) so that we could apply the sequential analysis program, GSEQ (Generalized Sequential Event Querier) (Bakeman \& Quera, 1996). The SDIS-GSEQ is supported by an analytical technique developed by Bakeman $(1978,1986)$ and by Sackett $(1979,1980,1987)$, from the records in the works performed by Bakeman \& Dabbs (1976), which continue to be of great relevance (Bakeman \& Quera, 2011) to analyze sequential data and, in the present research to observe the IRE and IRF patterns developed during the practice.

\subsection{Analysis Techniques}

The identification of statistically meaningful patterns in the flow speech was done by applying the sequential analysis techniques in the delays (Lags) and of temporary patterns as well (T-Patterns). The origins of the se- 
quential analysis of the delays as procedure of analysis of sequential datacome from the studies done by Sackett (1980, 1987), Bakeman (1978, 1991), Bakeman, Adamson, \& Strisik (1988), Bakeman \& Quera (1996, 2011, 2001) and Quera (1993). Such analysis detects sequential patterns of behavior (Quera, 1993), which is formed by looking for sequential contingencies among the categories of analysis, in this case they are sequential relations in the participants 'speeches.

\section{Results}

The information obtained by using the sequential analysis of the delays lets us see the probabilistic $\mathrm{Z}$ and $\mathrm{P}$ levels with which the discursive flow can be interpreted when selecting the adjusted waste and considering them as exciting ones when stimulating the appearance of a category (having a value of $Z>1.96$ ), or inhibitory if the adjusted waste is negative $(\mathrm{Z}<-1.96)$, showing that they prevent the negative category from appearing in the sequence.

Such data were divided in the most relevant elements that showed a comparison of categories given by the teacher and the practicing students in their instructing so as to get to observe the differences in their interaction with the rest of the participants in the practice, as shown in Figures 1-9.

In the case of the speech patterns, used by the teacher, when she explains instructing ( $M$ insexp, Figure 1) after the practicing student instructed correcting or answered asserting some student's action or evaluated grading; and once she instructs explaining buckles are generated when the teacher asks evaluating to then explain again, or in the case when the student holds the speech talking to her explaining, to then answer while explaining. The teacher's instructing while explaining can make the practicing student instruct commanding when there is no answer from the student.

The practicing student explains while instructing ( $\mathrm{P}$ insexp, Figure 2) after the teacher clarified some part of the subject matter or the student asked to verify what he understood or after him or other practicing student answered to clarify doubts, after the practicing student explained while instructing he himself can keep correcting or the student can keep asking.

The teacher employs models to explain ( $M$ insMexp, Figure 3), in case when she ordered while instructing and there was no student answer or when the practicing student guided while instructing, and whoever explains by using a model makes the teacher describe the action later on, or make the practicing student clarify concepts shown in the example, as well as a buckle with the student, when he asks, in doubt, about some knowledge so that she can give an example, after that the student keeps coming up with doubts.

On his own the practicing student usually starts explaining by using the model (P insMexp, Figure 4) after all of the students come up with doubts to the teacher when answering on the topic, once the model is used it takes us to buckle when the participants keep using it to explain which in the long run takes the student to keep asking to clarify doubts.

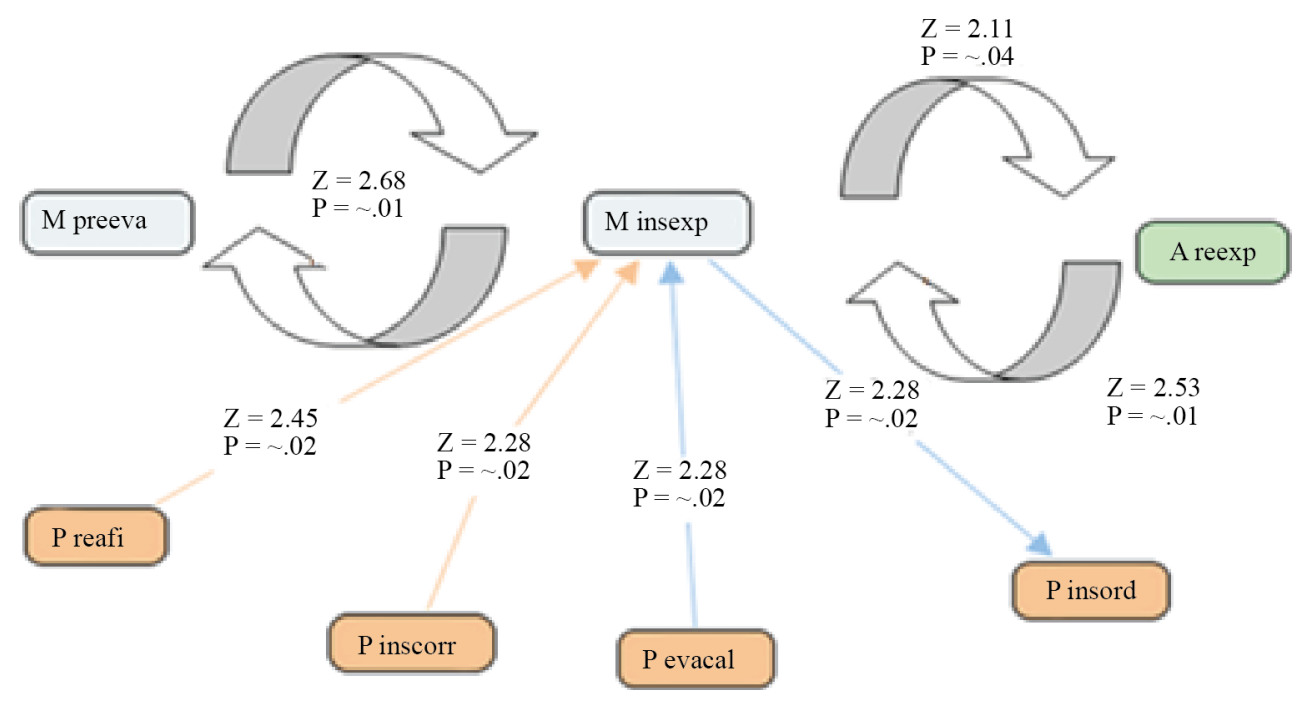

Figure 1. Flows of speech in the category M insexp. 


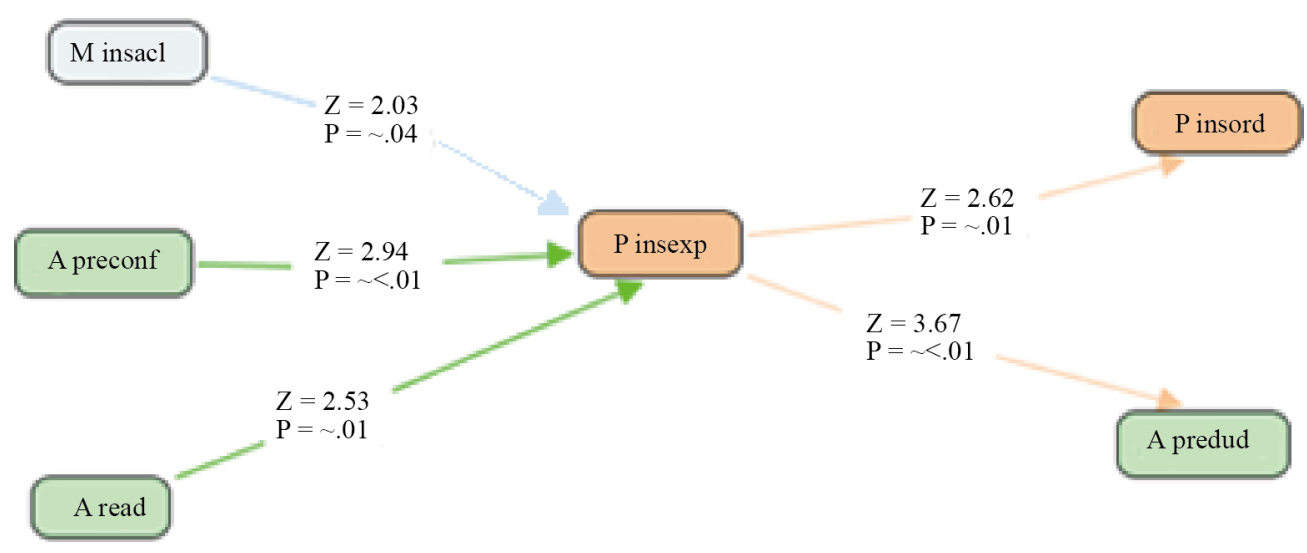

Figure 2. Flows of speech with the category P insexp.

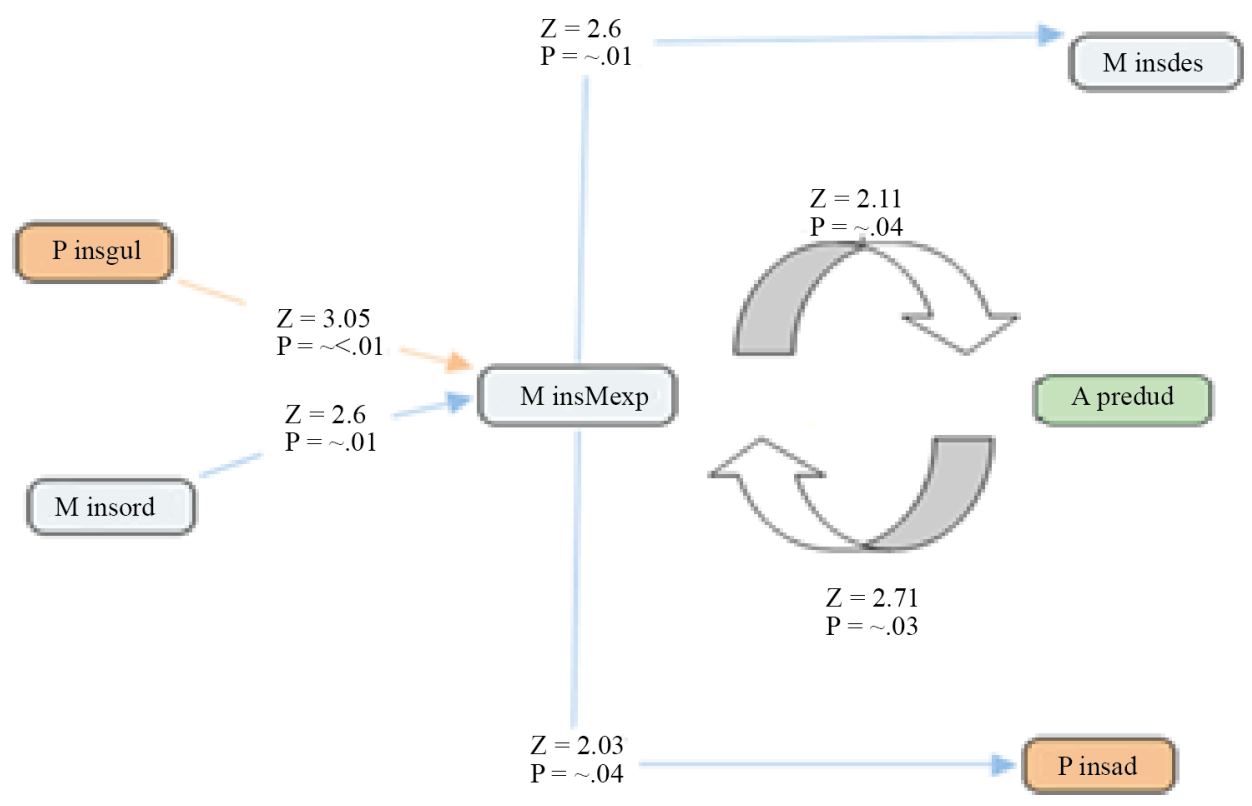

Figure 3. Flows of speech with the category M insMexp.

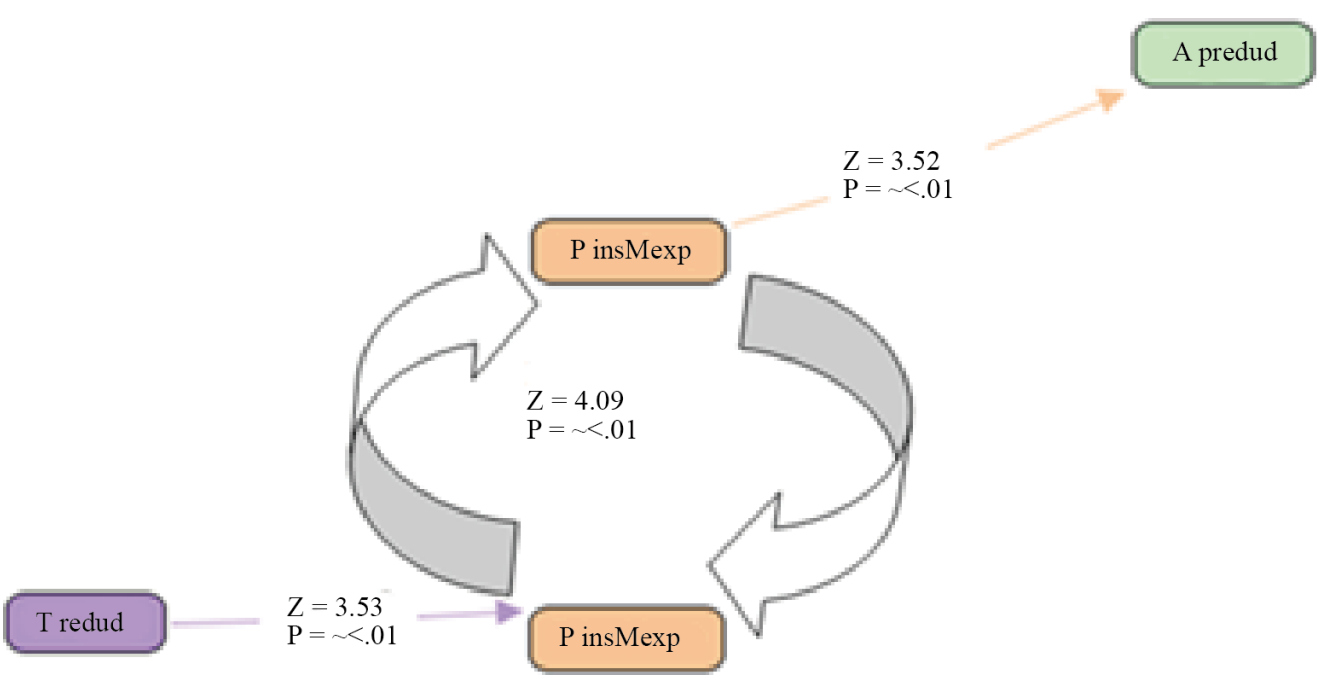

Figure 4. Flows of speech with the category P insMexp. 
Besides the use of instructions so as to explain, the teacher and practicing students also use some other linguistic strategies like ordering, clarifying and correcting:

The situation when the teacher orders while instructing the student's participation ( $M$ insord, Figure 5) has not an origin being observed by the program, and after ordering, the teacher makes the student answer by denying, or makes the practicing student evaluate while asking, or make the teacher keep explaining using it as a model or that the teacher asks again ordering the student's participation in the activity.

On the other hand, the practicing student ordering while instructing ( $\mathrm{P}$ insord, Figure 6) is caused when the teacher explains while instructing, or a student answers looking for other student's collaboration to fulfill the task, or when the practicing student itself evaluates while asking a certain person and such person doesn't answer, or when correcting while instructing, and grades while evaluating; after ordering there are no concrete actions either from the teacher or student, but the practicing student will keep the speech by asking, ordering to participate or by confirming whether the activity was or was not understood.

The teacher clarifies while instructing ( $M$ insad, Figure 7) after the student asked doubting; then the practicing student can continue the topic explaining while instructing. If the student answers in doubt, the teacher can continue clarifying the student's doubt generating a buckle. On the other hand, the practicing students clarify

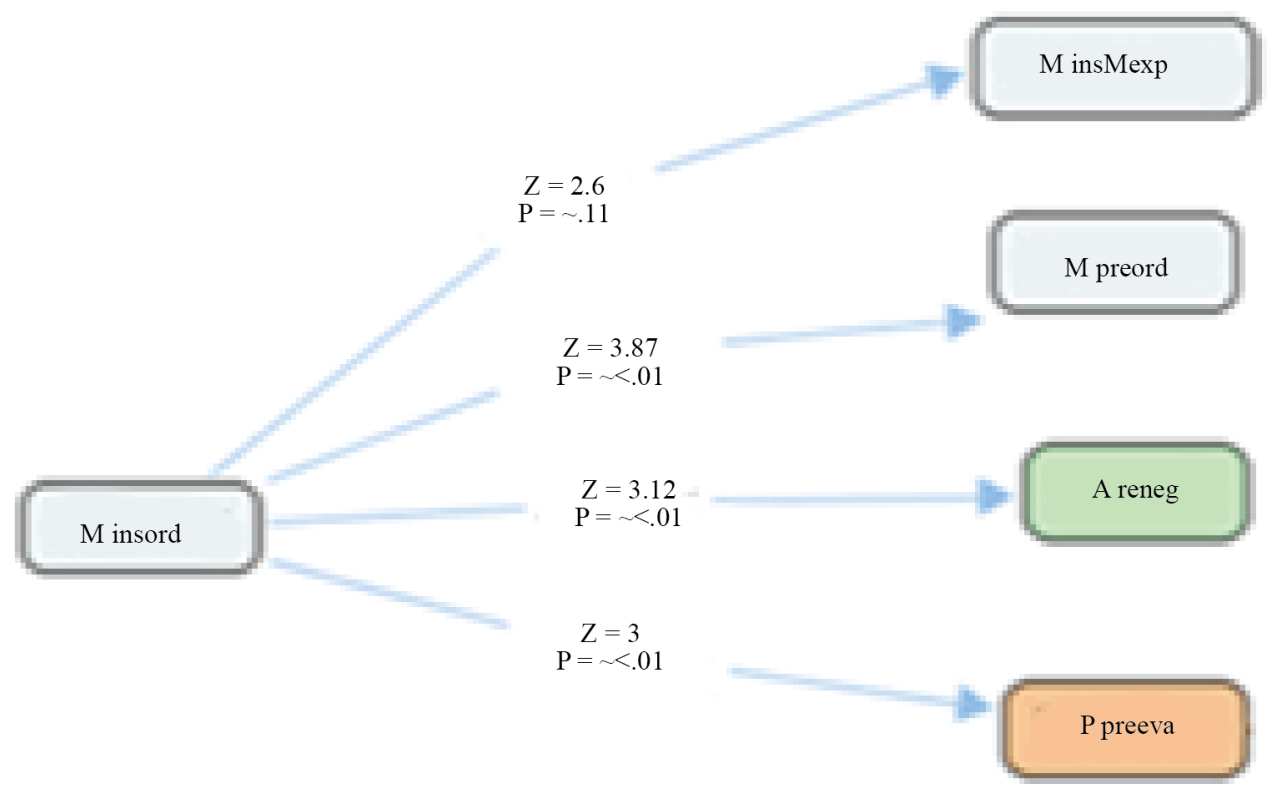

Figure 5. Flows of speech with the category M insord.

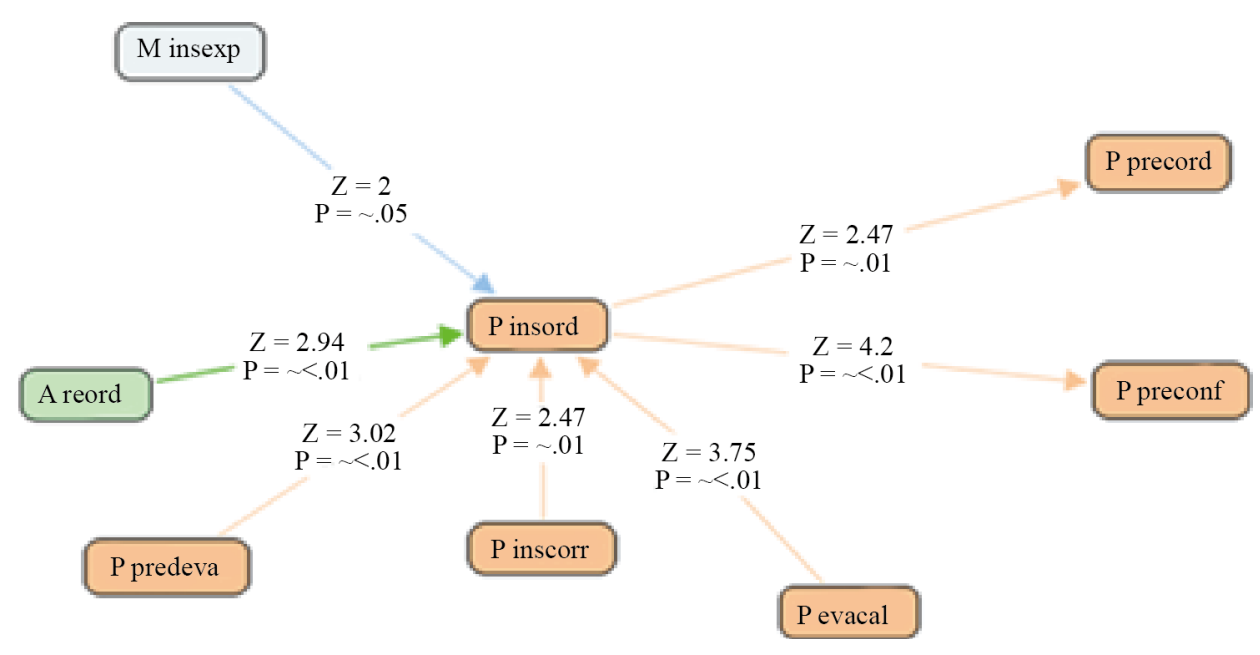

Figure 6. Flows of speech with the category P insord. 
while instructing (P insad, Figure 8) after the teacher used a model to explain, or if any student asserted while answering, or when this one answers while doubting; this makes the practicing student ask to make sure the doubts have been clarified.

The teacher's instruction while correcting ( $\mathrm{M}$ inscorr, Figure 9) has no origin or consequence found by the program. Likewise, the teacher, the practicing student has no concrete casual category so as to correct while instructing (P inscorr, Figure 9), but if the practicing student does so, it makes the student doubt while answering



Figure 7. Flows of speech with category M insad.

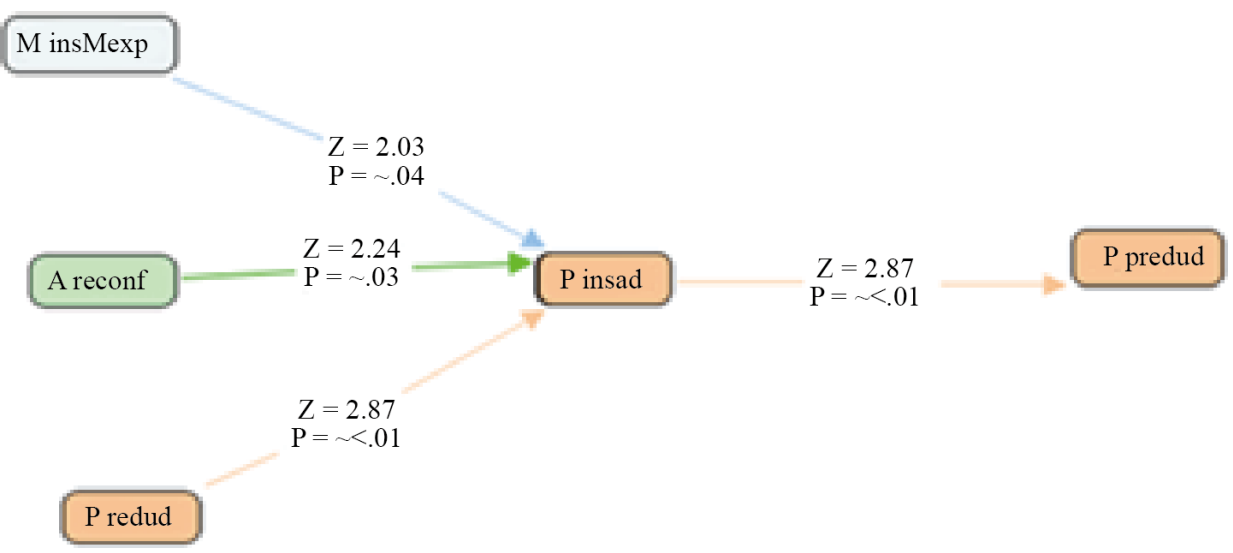

Figure 8. Flows of speech with category P insad.

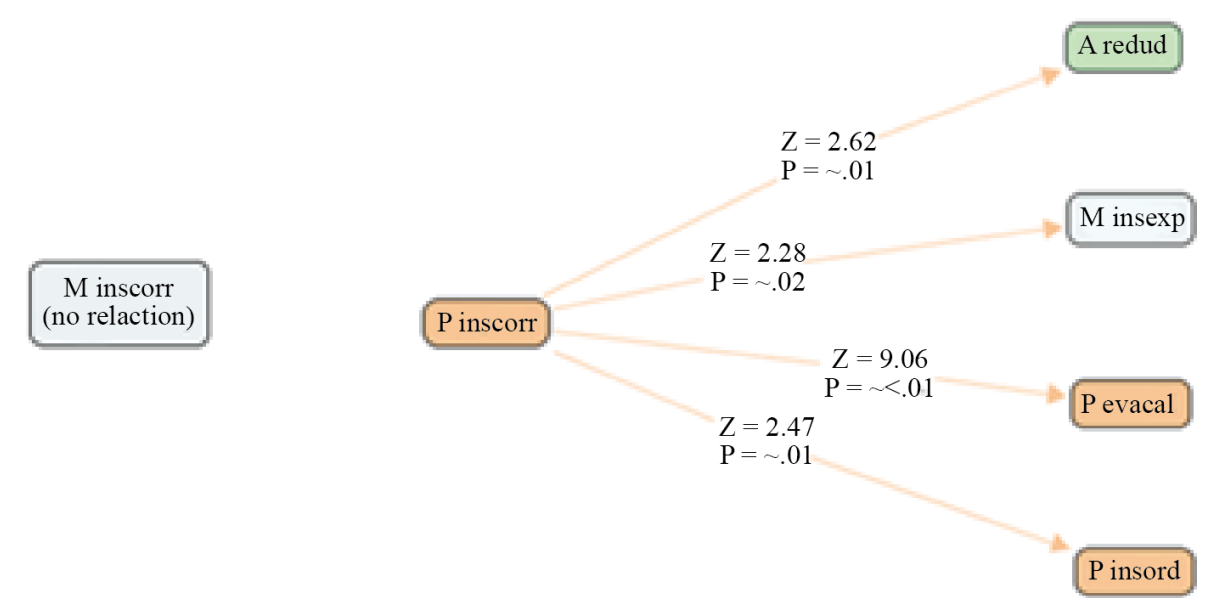

Figure 9. flows of speech with category $\mathrm{M}$ inscorr and $\mathrm{P}$ inscorr. 
or makes the teacher explain while instructing, that he or other practicing student grades while evaluating or instructs while ordering.

\section{Discussion}

The results show the variability generated by the practicing students as well as the teacher when executing the same category of action, proving the situated character of learning since each participant takes a differential role. While the teacher has a helping and guiding role, the practicing student incites the student to acquire the theoretical knowledge individually.

When we say that the teacher plays a helping and guiding role in the tasks concerning auscultation learning, we mean that the explanatory discursive structures bring an on-going dialog between the teacher and the student guiding with such ways of mediation from knowing to the desired knowledge. Furthermore, the practicing student discursive structure suggests that we are focusing on the student's good comprehension of the tasks in the practice before translating it to an action with someone else; employing in this way, stimulating actions (ordering while instructing) to get the student involved in the practice let it be possible for the student to participate after clarifying and asking whether there are doubts; reaffirming in this way, the knowledge is that the student is building around the context given in the classroom together with the teacher and getting a continued comparison and reflection of the knowledge shared with the students.

This introduces the practicing student with a double role as teacher and learner since the teacher uses IRE and modeling structures or guided learning depending on the use or absence of simulating models. While the practicing student uses or doesn't use the model itself, he only generates questions from the student when this one is doubting, which could suggest that even if the way the practicing student uses his discursive structures with the student is not perfect, using the structure lets the practicing student mediate his approach to the student and to the teacher's academic activity. Analogically speaking, the practicing student has a mediating role in the teacher-student relationship for having certain experience and due to their age, hence using both the hierarchical and stimuli structures, becoming a model as well.

Implementing these dynamics generates an environment where roles and activities of divergent care can be represented, which means simulations as the ones described by Pimienta (2012). This simulation can generate a situated learning, representing a current and empirical situation as the patient's palpation process in the professional environment; such activity lets us have reflexive and analytical points of view, which contributes to the student interaction, so they can solve their additional common doubts so that they can transmit their shared learning (Hernández \& Díaz, 2012).

The use of the differential model, both the student and the dummy generates conditions in which the student can connect the theoretical contents to the forms of their practice and can generate personal ways of practices, bringing some questioning and reflection about his doing and his co-building with his peers.

The way the teacher and the practicing student use the models tells us the way in the clinical and professional chores when caring for the patient. They are supported by the differential use of the speech; while the teacher plays the role of accompanying and involves the student as a patient/model to show to the rest of partners (the teacher makes the student come up front and be the model while she explains the doubts to the other students; in such situation the teacher is the professional and the student is the patient); the practicing students involve the student as a professional (the practicing student makes students come front up to explain how the procedures develop with the anatomic model to then ask if there are doubts, in that situation, the student is the professional and the model is the patient).

In this way, it can be stated that the know-how taught by the practicing student is directed to the student's appraisal as a future graduate having professional and technical knowledge, while the teacher directs the teaching towards professional and clinical knowledge at the same time while making them go through the situation of being patients.

The teacher's role can be compared to that one of a guide giving models, guidelines and tools which direct the mental activity of the students towards the learning objectives proposed, the teacher negotiates, while the practicing student's use of instructions request the student's action according to the student attitude and motivation, they let the students be incited while they are being motivated by the practice, giving a meaning to the construction of the knowledge they make of the knowledge for themselves and their peers. In this way, the importance of the speeches that make communication and action feasible in the context of the classroom due to the participants, are essential as they are the basic resources to fulfill any construction of shared knowledge if the action 
takes us to the explanation and comprehension of the topic instead of just reproducing it all.

\section{Acknowledgements}

We are grateful to the program PAPIME (PE304715) founded by the Universidad Nacional Autónoma de México, and the teachers and students of the Nursery Career on the Facultad de Estudios Superiores Iztacala.

\section{References}

American Psychological Association (2010). Ethical Principles of Psychologists and Code of Conduct. http://apa.org/ethics/code/index.aspx

Anguera, M. T., \& Izquierdo, C. (2006). Methodological Approaches in Human Communication. From Complexity of Situation to Data Analysis. In G. Riva, M. T. Anguera, B. K. Wiederhold, \& F. Mantovani (Eds.), From Communication to Presence. Cognition, Emotions and Culture towards the Ultimate Communicative Experience (pp. 207-225). Amsterdam: IOS Press.

Anzaldúa, R. (2004). La subjetividad y la relación educativa, una cuestión eludida. Revistatramas, 22, 31-54.

Bakeman, R. (1978). Untangling Streams of Behavior: Sequential Analysis of Observation Data. In G. P. Sackett (Ed.), Observing Behavior: Data Collection and Analysis Methods (Vol. 2, pp. 63-78). Baltimore: University of Park Press.

Bakeman, R. (1991). Prólogo. In M. T. Anguera (Ed.), Metodología observacional en la investigación psicológica (Vol. 1, pp. 13-24). Barcelona: PPU.

Bakeman, R., Adamson, L. B., \& Strisik, P. (1988). Lags and Logs: Statistic Approaches to Interaction. In M. H. Bornstein, \& Y. J. Bruner (Eds.), Interaction in Human Development (pp. 241-260). Hillsdale, NJ: Erlbaum.

Bakeman, R., \& Dabbs, J. M. (1976). Social Interaction Observed: Some Approaches to the Analysis of Behavior Streams. Personality and Social Psychology Bulletin, 2, 335-345. http://dx.doi.org/10.1177/014616727600200403

Bakeman, R., \& Gottman, J. M. (1986). Observación de la interacción: Introducción al análisis secuencial. Madrid: Morata.

Bakeman, R., \& Quera, V. (1996). Análisis de la interacción: Análisis secuencial con SDIS y GSEQ. Madrid: Ra-Ma.

Bakeman, R., \& Quera, V. (2001). Using GSEQ with SPSS. Metodología de las Ciencias del Comportamiento, 3, $195-214$.

Bakeman, R., \& Quera, V. (2011). Sequential Analysis and Observational Methods for the Behavioral Sciences. Cambridge: Cambridge University Press. http://dx.doi.org/10.1017/CBO9781139017343

Candela, A. (1993). La construcción discursiva de la ciencia en el aula. Investigación en la Escuela, 21, 31-38.

Candela, A. (1996). La construcción discursiva de contextos argumentativos en la enseñanza de la ciencia. In C. Coll, \& Y. D. Edwards (Eds.), Enseñanza, aprendizaje y discurso en el aula. Aproximaciones al estudio del discurso educacional (pp. 99-116). Madrid: Fundación Infancia y Aprendizaje.

Candela, A. (1999). Ciencia en el aula. Los alumnos entre la argumentación y el consenso. México: Paidós.

Cazden, C. B. (2001) Classroom Discourse: The Language of Teaching and Learning (2nd ed.). Portsmouth: Heinemann.

Coll, C., Colomina, R., Onrubia, J., \& Rochera, M. J. (1992). Actividad conjunta y habla: una aproximación al estudio de los mecanismos de influencia educativa. Infancia y Aprendizaje, 59-60, 189-232. http://dx.doi.org/10.1080/02103702.1992.10822356

Coll, C., \& Onrubia, J. (2001). Estrategias discursivas y recursos semióticos en la construcción de significados compartidos entre profesores y alumnos. Investigaciónen la escuela, 45, 7-19.

Drew, P. (1995). Conversation Analysis. In A. Jonathan, R. H. Smith, \& L. V. Langenhove (Eds.), Rethinking Methods in Psychology (pp. 64-79). London: Sage. http://dx.doi.org/10.4135/9781446221792.n5

Driver, R., Asoko, H., Leach, J., Mortimer, E., \& Scott, P. (1994). Constructing Scientific Knowledge in the Classroom. Educational Researcher, 23, 5-12. http://dx.doi.org/10.3102/0013189X023007005

Edwards, D. (1990). El papel del profesor en la construcción social del conocimiento. Investigaciónen la Escuela, $10,33-50$.

Edwards, D., \& Mercer, N. (1986). Context and Continuity: Classroom Discourse and the Development of Shared Knowledge. In K. Durkin (Ed.), Language Development in the School Years (pp. 172-202). London, UK: Croom Helm

Edwards, D., \& Middleton, D. (1986). Joint Remembering: Constructing an Account of Shared Experience through Conversational Discourse. Discourse Processes, 9, 423-459. http://dx.doi.org/10.1080/01638538609544651

Edwards, D., \& Westgate, D. (1994). Investigating Classroom Talk. London: The Falmer Press.

Hernández, J. L., \& Díaz, R. (2012). Aprendizaje Situado: Transformar la realidad educando. México: Grupo Gráfico Editorial.

Mercer, N. (1995). The Guided Construction of Knowledge. Talk amongst Teachers and Learners. Clevedon: Multilingual 
Matters Ltd.

Nassaji, H., \& Wells, G. (2000). What's the Use of “Triadic Dialogue”? An Investigation of Teacher-Student Interaction. Applied Linguistics, 21, 376-406. http://dx.doi.org/10.1093/applin/21.3.376

Rogoff, B. (1990). Apprenticeship in Thinking. Cognitive Development in Social Context. New York: Oxford University Press.

Pimienta, J. H. (2012). Estrategias de Enseñanza-Aprendizaje: docencia universitaria basada en competencias. México: Pearson Educación.

Potter, J. (1996). Representing Reality. Discourse, Rhetoric and Social Construction. Londres: SAGE. http://dx.doi.org/10.4135/9781446222119

Quera, V. (1993). Análisis Secuencial. In M. T. Anguera (Ed.), Metodología observacional en la investigación psicológica (pp. 341-586). Barcelona: PPU.

Sackett, G. P. (1979). The Lag Sequential Analysis of Contingency and Cyclicity on Behavioral Interaction Research. In J. D. Osofsky (Ed.), Handbook of Infant Development (pp. 623-649). New York: Wiley.

Sackett, G. P. (1980). An Initial Investigation of the Usability of Conversational Data for Doing Sociology. In D. Sudnow, (Ed.), Studies in Social Interactions (pp. 31-74). New York: Free Press.

Sackett, G. P. (1987). Analysis of Sequential Social Interaction Data: Some Issues, Recent Developments, and Causal Inference Model. In J. Osofsky (Ed.), Handbook of Infant Development (pp. 855-878). New York: Wiley.

Stierer, B., \& Maybin, J. (1994). Language, Literacy and Learning in Educational Practice. Clevedon: Multilingual Matters.

Wood, D., Bruner, J. S., \& Ross, G. (1976). The Role of Tutoring in Problem Solving. Journal of Child Psychology and Psychiatry, 17, 89-100. http://dx.doi.org/10.1111/j.1469-7610.1976.tb00381.x 